\title{
CROSSBREEDING IN SHEEP FOR MEAT PRODUCTION
}

G. WIENER. - Animal Breeding Research Organisation, West Mains Road, Edinburgh, EH9 $3 J X$.

Results were reviewed from studies involving comparisons of the performance of different breeds of sheep and their crosses particularly in relation to body size, reproductive and maternal performance, carcass attributes and aspects of mineral metabolism. Crossbreds offer a wide range of performance specifications for an almost infinite variety of farming systems and market requirements, but in most cases heterosis appeared to play only a relatively small part in determining crossbred performance in respect of " single' traits, altough at times this part may be important. Among the examples cited, heterosis had a large effect only in determining levels of calcium and copper in blood of crosses among the particular breeds examined. In general, estimates of heterosis were found to vary greatly not only for different traits but from cross to cross when the " same" trait was considered. This suggests that the magnitude of heterosis is not readily predictable for specific breed combinations. However, the value of crossbreeding in a farming system should not be assessed only in relation to single traits, but should be considered for combination of traits and for the profitability of the system. There is insufficient evidence on the magnitude of 6 profit heterosis ?.

\section{ERGEBNISSE EINES HYBRIDZUCHTVERSUCHES}

\section{AUF DER BASIS VON MERINOLANDSCHAFEN}

\section{G. Nirter. - Abteilung für Tierzuchtung Universität Hohenheim Landwirtschaftliche Hochschule 7 Stuttgart 70, Postfach 106 (BRD).}

Es wird von einem Kreuzungsversuch berichtet, der in der Zeit von 1969 bis I973 auf zwei Versuchsgütern der Universität Hohenheim lief.

Je 50 Muttertiere aus je ro Halbgeschwistergruppen von 4 (Meiereihof) bzw. 6 (Oberer Lindenhof) verschiedenen Kreuzungskombinationen aul der Basis von Merinolandschafen wurden mit je ro Böcken aus 4 englischen bzw. Französischen Fleischrassen über 3 bzw. 5 Deckperioden angepaart. Alle in diesem Zeitraum geborenen Lämmer (durchschnittlich 40 je Untergruppe) wurden einer Intensivmast zugeführt und versuchsmässig ausgeschlachtet. Die Aufzucht der Lämmer erfolgie im Meiereihof bei ausschliesslicher Frühjahrslammung herkömmlich an der Mutter, auf dem Oberen Lindenhof bei mehrmaligem Ablammen je Jahr mit Hilfe von Milchaustauschern.

Ein wirtschaftlicher Vergleich der geprüften Linienkombinationen ergibt, dass unter Haltungsbedingungen, die eine verlustarme Lämmeraufzucht ermöglichen (z. B. mutterlose Aufzucht überzähliger Lämmer), Muttertiere mit einem 50 prozentigen Genanteil vom Finnischen Landschaf bei Anpaarung mit Böcken aus Fleischlinien trotz geringerer Wollerlöse sowie Geburts - und Schlachtkörpergewichte ihrer Lämmer einen deutlich höheren Gewinn abwerfen als Muttertiere anderer Linienkombinationen einschliesslich der Kontrolltiere (Merinolandschaf). Die Versuchsergebnisse zeigten für die wirtschaftlich wichtigen Merkmale keine Anzeichen für eine spezielle Kombinationseignung spezifischer Linienkombinationen und keine bedeutsamen Differenzen in der allgemeinen Kombinationseignung der geprluftenVaterlinien.

\section{COMPARISON OF SIRE BREEDS}

\section{FOR CROSSBRED LAMB PRODUCTION}

\section{FROM NEW ZEAL,AND ROMNEY EWES}

\section{A. H. CARTER. - Ministery of Agriculture and Fisheries, Ruakura Animal Research Station, Hamilton (New Zealand).}

Salient features of the New Zealand prime lamb production industry, traditionnally based on the Southdown ram crossed with the Romney ewe, are discussed. The paper reports an extensive series of experiments involving approximately 15000 Romney ewes mated with 435 rams of 15 breeds. 
The main conclusions are :

I. Important differences exist between sire breeds in progeny survival with the Southdown being best and the Romney poorest.

2. Progeny of long-wool sires, and particularly the Lincoln, clip more wool at post-weaning shearing than of the Down breeds, which exhibit quite small variation.

3. Sire breeds vary in average liveweight growth of their progeny, the Suffolk, Hampshire and Dorset breeds producing the heaviest and the Merino and Romney the lightest lambs.

4. Within any breed wide differences exist between progeny growth rates of the best and poorest sires, emphasizing the great importance of sound selection of rams and of adequate genetic sampling in breed comparisons.

5. In terms of lamb liveweight production per Romney ewe mated, Romney, Merino, Lincoln Ryeland, Cheviot and English Leicester sires are inferior to the Southdown while Poll Dorset or Dorset Horn, Suffolk, South Suffolk and Dorset Down are slightly superior.

\title{
THE CHOICE OF SIRE BREED
}

AND SLAUGHTER WEIGHT FOR LAMB PRODUCTION

\author{
P. W. Knapman, E. Owen.
}

A $3 \times 3 \times 2$ factorial experiment is being carried out and involving 3 breeds of sire; Southdown, Suffolk and Cotswold to a common dam line, the Finnish Landrace $\times$ Dorset Horn.

Two planes of nutrition are used, ad libitum and restricted $i$. $e$. restricted to grow at $2 / 3$ the average growth rate shown by those comparable lambs on ad lib. intake. Entire males and females are compared. All progeny were individually penned after weaning at $18 \mathrm{p}$. Ioo mid - parent weight (i.e. approx. 5 weeks old) and fed on 87 p. Ioo rolled barley diet containing I 5 p. roo crude protein in the dry matter. Lambs were slaughtered at $40,50,60$ and $70 \mathrm{p}$. Ioo midparent weight. The left side of each lamb was physically dissected into lean, bone, submuscular and intramuscular fat and waste. Scatter diagrams were drawn and within trial and group relationships between weight of carcass tissue and carcass weight were judged to arithmetically linear. However marked differences in slopes and some differencies in intercepts were noted. Multiple regression was used to quantify the interaction found by use of a linear model. The resulting coefficients gave a quantitative partition of the treatment and interaction effects on slope and intercepts. Significant differences in intercept were attributable only to breed of sire, in particular the Cotswold sired lambs within lower levels of fat and higher levels of lean tissue. The effects in slope were more diverse and more important with significant effects for breed, sex and interaction between breed and sex, sex and nutrition and between breed, sex and nutrition.

In practical terms, Southdown crosses appear to be unsuitable for this intensive production system. The Cotswold is well suited to sire lambs to be slaughtered at weight between 30 and $40 \mathrm{~kg}$ live weight. A greater sex differential within the Suffolk crosses suggested that female lambs are unsuitable, whereas male lambs for which growth is restricted may be taken to comparatively heavy weights to produce carcases of about $25 \mathrm{~kg}$.

\section{THE SIGNIFICANCE OF RAM BREED AND EWE BREED IN CROSSBREEDING FOR MEAT PRODUCTION FROM SHEEP IN AN INTENSIVE SYSTEM}

T. G. Boaz, W. M. Tempest, R. Jones. - Department of Animal Physiology and Nuirition, The University of Leeds, England.

It is necessary to measure the merit of crossbreeding for meat production from sheep in terms of yield of meat per hectare and the acceptability of the carcase to the consumer. The efficiency of meat production is governed by the reproductive rate of the flock and the rate of growth of the lambs, both in relation to the size of ewe which in turn governs stocking rate. Acceptability of the carcase depends on its weight and basically on its component muscle : bone ratio and fat percentage. 